\title{
The enduracidin biosynthetic gene cluster from Streptomyces fungicidicus
}

\author{
Correspondence \\ Xihou Yin \\ yinx@onid.orst.edu \\ T. Mark Zabriskie \\ mark.zabriskie@oregonstate.edu
}

Received 6 April 2006

Revised 16 June 2006

Accepted 6 July 2006

\author{
Xihou Yin and T. Mark Zabriskie \\ Department of Pharmaceutical Sciences, College of Pharmacy, Oregon State University, \\ Corvallis, OR 97331-3507, USA
}

\begin{abstract}
The biosynthetic gene cluster for the 17 aa peptide antibiotic enduracidin has been cloned and sequenced from Streptomyces fungicidicus ATCC 21013. The 84 kb gene cluster contains 25 ORFs and is located within a $116 \mathrm{~kb}$ genetic locus that was fully sequenced. Targeted disruption of non-ribosomal peptide synthetase (NRPS) genes in the cluster abolished enduracidin production and confirmed function. The cluster includes four genes, end $A-D$, encoding two-, seven-, eight- and one-module NRPSs, respectively, and includes unique modules for the incorporation of citrulline and enduracididine. The NRPS organization generally follows the collinearity principle, and starts with a condensation domain ( $C$ domain) similar to those found in other lipopeptide systems for the coupling of an acyl group to the starting amino acid. The sixth module of EndB, corresponding to $\mathrm{Thr}^{8}$, is missing an adenylation domain (A domain) and this module is presumed to be loaded in trans by the single module protein EndD. The most striking feature of the NRPS organization is the lack of epimerization domains (E domains) in light of the fact that the product has seven D-amino acid residues. Sequence analysis reveals that $\mathrm{C}$ domains following modules corresponding to $\mathrm{D}$-amino acids belong to a unique subset of $\mathrm{C}$ domains able to catalyse both epimerization and condensation reactions. Other genes directing lipid modification and activation, and formation of the nonproteinogenic amino acids 4-hydroxyphenylglycine and enduracididine are readily identified, as are genes possibly involved in regulation of antibiotic biosynthesis and export. These findings provide the basis to further genetically manipulate and improve lipodepsipeptide antibiotics via combinatorial and chemical methods.
\end{abstract}

\section{INTRODUCTION}

The global emergence of multidrug-resistant bacterial infections has resulted in enormous healthcare costs and has become a major threat to public health. In the USA alone, the total cost linked to antibiotic-resistant infections has been estimated at US $\$ 5$ billion annually (Zinner, 2005). Since its launch in 1958, vancomycin was the drug of last resort for treating Gram-positive pathogens such as methicillin-resistant Staphylococcus aureus (MRSA) (Barrett, 2005). However, vancomycin-resistant S. aureus strains have emerged and over $28 \%$ of enterococci responsible for intensive care unit infections in the USA are now vancomycin-resistant (Tenover \& McDonald, 2005). In addition, resistance to the newest antibiotics to treat these infections, linezolid and daptomycin, has already

Abbreviations: Am, apramycin; Cit, L-citrulline; Dpg, 3,5-dichloro-L-4hydroxyphenylglycine; End, D- and L-enduracididine; Hpg, D- and L-4hydroxyphenylglycine; MRSA, methicillin-resistant Staphylococcus aureus; NRPS, non-ribosomal peptide synthetase; Orn, D-ornithine; PCP, peptidyl carrier protein; PDH, prephenate dehydrogenase; VRE, vancomycin-resistant Enterococcus faecium.

The GenBank/EMBL/DDBJ accession number for the sequence reported in this paper is DQ403252. been described (Mangili et al., 2005; Meka et al., 2004; Tsiodras et al., 2001). To stay ahead of the development of antibacterial drug resistances, there is a pressing necessity to identify new antibiotics, especially those with novel mechanisms of action.

Enduracidin is a 17 aa lipodepsipeptide produced by the soil bacterium Streptomyces fungicidicus ATCC 21013 (Fig. 1). The peptide is isolated from the fermentation broth and mycelia as a mixture of enduracidins $A$ and $B$, which differ in the length of the attached lipid chain (Hori et al., 1973; Iwasaki et al., 1973). The only characterized analogue of enduracidin is ramoplanin (Fig. 1), which is currently in Phase III clinical trials for the oral treatment of intestinal vancomycin-resistant Enterococcus faecium (VRE) and in phase II trials for nasal MRSA (Fang et al., 2006; Walker et al., 2005). At present, there is no known form of developed or acquired resistance to ramoplanin or enduracidin.

Like ramoplanin, enduracidin is active towards a wide variety of Gram-positive bacteria, including VRE and MRSA (Goto et al., 1968; Kawakami et al., 1971; Komatsuzawa et al., 1994; Peromet et al., 1973; Tsuchiya et al., 1968; Yourassowsky \& Monsieur, 1972). These peptides disrupt 

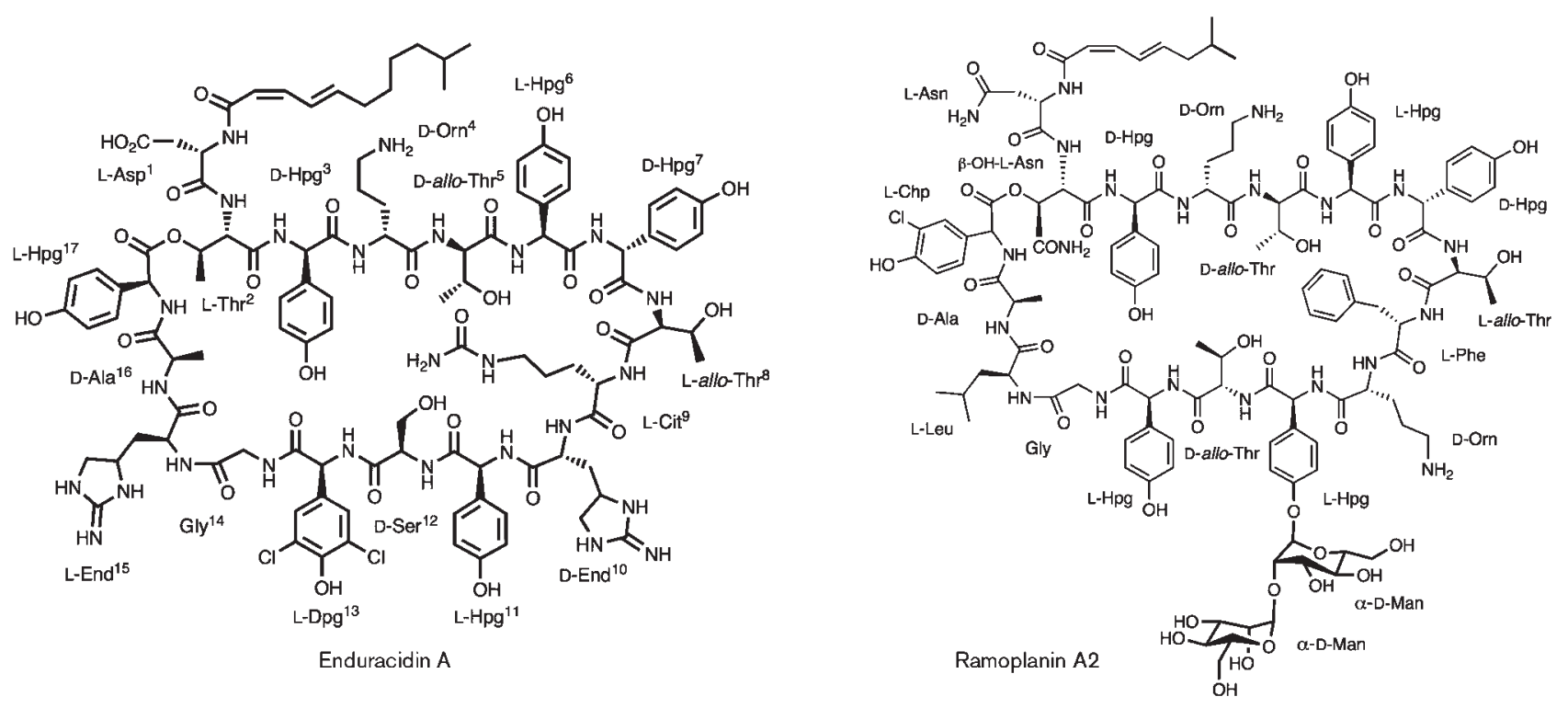

Fig. 1. Structures of enduracidin A and ramoplanin $A 2$.

bacterial cell wall biosynthesis, but have a mechanism of action that is distinct from the $\beta$-lactams and vancomycin. Enduracidin and ramoplanin block the elongation step of peptidoglycan biosynthesis by binding to the transglycosylase substrate Lipid II (Cudic et al., 2002; Fang et al., 2006). This substrate-binding mechanism is analogous to the vancomycin mode of action, but these different peptide antibiotics recognize distinct regions of Lipid II. The promising activity and unique mode of action of enduracidin, coupled with novel structural features and intriguing questions in the biosynthesis, make this peptide an attractive target for further antibiotic development studies. As a first step to facilitate such studies, we have localized the enduracidin biosynthetic gene cluster to a $116 \mathrm{~kb}$ contiguous segment of the S. fungicidicus ATCC 21013 chromosome, cloned the cluster on a set of overlapping fosmid inserts and completed the DNA sequence of this region. Initial genetic characterization of the gene cluster through disruption of non-ribosomal peptide synthetase (NRPS) genes confirmed the involvement in enduracidin biosynthesis.

\section{METHODS}

Bacterial strains, plasmids, fosmids and culture conditions. Streptomyces fungicidicus ATCC 21013 and Escherichia coli S17-1 (ATCC 47055) were purchased from ATCC. E. coli strains DH5 $\alpha$ (Life Technologies Inc.), EPI300 (Epicentre) and XL10-Gold (Stratagene) were routinely used as hosts for E. coli plasmids, fosmids and E. coli-Streptomyces shuttle vectors. Plasmid pSET152 (Bierman et al., 1992) was obtained from Professor K. F. Chater (Norwich), the pGEM-T easy cloning vector was from Promega and the pCC1FOS system was purchased from Epicentre. Media and culture conditions for S. fungicidicus were described by Higashide et al.
(1968). All E. coli procedures were performed according to standard protocols (Sambrook \& Russell, 2001). Standards of enduracidin A and B were purchased from Sigma-Aldrich.

DNA isolation and manipulations. Isolation of chromosomal DNA from $S$. fungicidicus and agarose gel electrophoresis were performed according to Kieser et al. (2000), and QIAprep Spin Miniprep kits (Qiagen) were used to prepare plasmids and fosmids from E. coli strains. Restriction endonucleases, DNA ligase, DNA polymerase and alkaline phosphatase were purchased from various sources and used according to the manufacturers' recommendations. DNA fragments were purified using QIAquick Gel Extraction kits (Qiagen).

Generation of NRPS and prephenate dehydrogenase (PDH) gene probes. PCR primers were designed to amplify internal fragments of NRPS genes, corresponding to the region between conserved motifs A3 and T (Marahiel et al., 1997). Primer design took into consideration Streptomyces codon bias (Wright \& Bibb, 1992). The degenerate primers were PSA3f, 5'-ATCTACACSTCSGGCACSACSGGCAAGCCSAAGGG-3', and PSTr, 5'-AWIGAGKSICCICCSRRSIMGAAGAA-3' $(\mathrm{S}=\mathrm{G}+\mathrm{C} ; \mathrm{W}=\mathrm{A}+\mathrm{T} ; \mathrm{K}=\mathrm{T}+\mathrm{G} ; \mathrm{R}=$ $\mathrm{G}+\mathrm{A} ; \mathrm{M}=\mathrm{A}+\mathrm{C} ; \mathrm{I}=$ inosine). The PCR template was $S$. fungicidicus genomic DNA digested with HindIII, BamHI or BglII. PCR mixtures (final volume of $100 \mu \mathrm{l}$ ) contained $2 \cdot 5 \mu \mathrm{g}$ digested chromosomal DNA, 100 pmol each primer, $0 \cdot 25 \mathrm{mM}$ dNTPs, Taq DNA polymerase reaction buffer without $\mathrm{MgCl}_{2}$ (Promega), $1.5 \mathrm{mM} \mathrm{MgCl}, 5 \%$ DMSO and $1 \mu \mathrm{l}$ polymix (added at $80^{\circ} \mathrm{C}$ ) from the Expand Long Template PCR System (Roche). PCR was performed as follows: 1 cycle for $3 \mathrm{~min}$ at $95^{\circ} \mathrm{C}$ and $1 \mathrm{~min}$ at $80^{\circ} \mathrm{C}, 30$ cycles for $1 \mathrm{~min}$ at $95^{\circ} \mathrm{C}, 1 \mathrm{~min}$ at $55^{\circ} \mathrm{C}$ and $2 \mathrm{~min}$ at $72^{\circ} \mathrm{C}$. The reaction was terminated with one extension cycle at $72{ }^{\circ} \mathrm{C}$ for $10 \mathrm{~min}$. PCR products of the correct size $(1.2 \mathrm{~kb})$ were gel-purified and cloned into the pGEM-T easy vector. DNA sequence analysis of randomly selected clones revealed five unique plasmids: pGEMTE-sfPS5, pGEMTEsfPS9, pGEMTE-sfPS11, pGEMTE-sfPS15 and pGEMTE-sfPS18.

To amplify a PDH gene probe, degenerate oligonucleotide primers (Pdhf, 5'-GGSACCGGSCTSATCGGBACSTCS-3', and Pdhr, 5'-GTGSGAGACGAGSGCCACSGCSCGGTCGTG-3'; S=G + C, $\mathrm{B}=\mathrm{G}+\mathrm{C}+\mathrm{T}$ ) were designed based on the alignment of $\mathrm{PDH}$ proteins 
from Actinoplanes sp. ATCC 33076 (AX417445), S. coelicolor A3(2) (NP733544) and S. avermitilis MA-4680 (NP827697). The PCR conditions were the same as described above. An amplicon of the expected size $(0.5 \mathrm{~kb})$ was purified and cloned into the pGEM-T easy vector to obtain plasmid pGEMTE-sfPdh-Nt. DNA sequence analysis confirmed that the insert (538 bp) encodes the $\mathrm{N}$-terminal portion of a putative $\mathrm{PDH}$.

Inactivation of enduracidin NRPS genes. The NRPS substrate specificity sequences extracted from the insert of pGEMTE-sfPS11, pGEMTE-sfPS15 and pGEMTE-sfPS18 predicted that they activate Thr, Hpg and Asp, respectively, and are consistent with involvement in enduracidin formation (Challis et al., 2000; Rausch et al., 2005; Stachelhaus et al., 1999). These plasmid inserts were used to construct gene disruption plasmids in vector pXY300, an E. colil Streptomyces temperature-sensitive conjugal vector (Yin et al., 2003). A $1 \mathrm{~kb}$ fragment from plasmid pSET152 carrying the aac(3)IV gene conferring apramycin resistance $\left(\mathrm{Am}^{\mathrm{R}}\right)$ was amplified by PCR using primers that introduced BamHI/HindIII restriction sites at both ends (apraRf, 5' -CACGGATCCAAGCTTGGTTCATGTGCA-3', and apraRr, 5' -ATCGGATCCAAGCTTCACGTGTTGC-3'; BamHI/ HindIII sites are in bold). The gene disruption plasmids were constructed as follows. The $\mathrm{Am}^{\mathrm{R}}$ fragment was ligated with the unique BglII site in the insert of pGEMTE-sfPS11 to yield plasmid pGEMTE-sfPS11-Am ${ }^{\mathrm{R}}$. The insert of pGEMTE-sfPS11-Am ${ }^{\mathrm{R}}$ was excised with EcoRI and ligated with similarly restricted pXY300 to obtain the final construct, pXY300-sfPS11-Am ${ }^{\mathrm{R}}$. Site-directed mutagenesis was used to introduce BglII restriction sites near the middle of the pGEMTE-sfPS15 and pGEMTE-sfPS18 inserts. Two sets of primers were synthesized (sfPS15BglIIf, 5'-TCTACGTCCTGGACAGATCTCTGAACCCGGTG-3', and sfPS15BglIIr, 5' -CACCGGGTTCAGAGATCTGTCCAGGACGTAGA-3'; sfPS18BglIIf, 5'-TCAACCCCGTACCCGTCAGATCTCTGGGGGAGCT-3', and sfPS18BglIIr, 5'-AGCTCCCCCAGAGATCTGACGGGTACGGGGTTGA-3'; BglII sites are in bold) and the desired BglII sites were created using the QuikChange Site-directed Mutagenesis kit (Stratagene), following the manufacturer's protocol. The $\mathrm{Am}^{\mathrm{R}}$ fragment was ligated into the newly created BglII sites to produce plasmids pGEMTE-sfPS15-Am ${ }^{\mathrm{R}}$ and pGEMTE-sfPS18-Am ${ }^{\mathrm{R}}$. The inserts of these two plasmids were excised by EcoRI digestion and ligated with the similarly restricted pXY300 to give the final constructs, pXY300-sfPS15-Am ${ }^{\mathrm{R}}$ and pXY300-sfPS18-Am ${ }^{\mathrm{R}}$.

The gene disruption plasmids were individually introduced into E. coli S17-1 by transformation and then conjugation with S. fungicidicus was carried out according to the literature (Kieser et al., 2000). Briefly, freshly harvested S. fungicidicus spores were pre-germinated and E. coli S17-1 cells were grown overnight at $37^{\circ} \mathrm{C}$ in Terrific broth (Sambrook \& Russell, 2001). Serial dilutions of the germinated spore suspension were made and $100 \mu \mathrm{l}$ of each dilution was mixed with an equal volume of E. coli S17-1 harbouring the pXY300-based disruption plasmids. The solutions were plated onto ISP4 agar plates with addition of $10 \mathrm{mM}$ $\mathrm{MgCl}_{2}$ and incubated for $22 \mathrm{~h}$ at either 30 or $37^{\circ} \mathrm{C}$. Each plate was overlaid with $3 \mathrm{ml}$ soft nutrient agar containing sodium nalidixate and Am $\left(0.5 \mathrm{mg}\right.$ each $\left.\mathrm{ml}^{-1}\right)$ and further incubated at $30^{\circ} \mathrm{C}$ for about 1 week. Isolated exconjugants that survived antibiotic selection were purified by streaking onto ISP4 agar plates supplemented with sodium nalidixate and Am $\left(50 \mu \mathrm{g}\right.$ each $\left.\mathrm{ml}^{-1}\right)$.

To conduct the gene disruption experiments, exconjugants were first cultured in TSB liquid medium containing Am $\left(5 \mu \mathrm{g} \mathrm{ml}{ }^{-1}\right)$ at $30^{\circ} \mathrm{C}$ for $24 \mathrm{~h}$ at which time the mycelia were harvested, homogenized and used to inoculate TSB and YEME liquid media supplemented with Am $\left(5 \mu \mathrm{g} \mathrm{ml}^{-1}\right)$. After $3-6$ days incubation at $40^{\circ} \mathrm{C}$, the mycelia were homogenized and plated onto ISP4 agar plates containing Am $\left(50 \mu \mathrm{g} \mathrm{ml}^{-1}\right)$ and incubated at $30^{\circ} \mathrm{C}$ for 1 week. Genomic DNA was isolated from randomly selected individual surviving colonies and analysed by Southern blotting to confirm that single- or doublecrossover disruption had occurred.

Construction of S. fungicidicus genomic libraries. Genomic DNA was prepared from S. fungicidicus ATCC 21013 wild-type and disruptant strains according to Kieser et al. (2000). Three genomic libraries were constructed using the CopyControl Fosmid Library Production kit and EPI300 E. coli plating strain (Epicentre), following the manufacturer's specifications. Briefly, chromosomal DNA was end-repaired and fractionated on a $1 \%$ low-melting-point agarose gel. The band at approximately $40 \mathrm{~kb}$ was excised and recovered from the agarose gel. After gelase digestion, the DNA was precipitated with sodium acetate and ethanol. Purified genomic DNA was ligated with linearized, dephosphorylated pCC1FOS $^{\mathrm{M}}$ vector at room temperature for $2 \mathrm{~h}$. The ligation mixture was packaged using MaxPlax Lambda Packaging Extract (Epicentre) followed by transfection into E. coli EPI300 cells.

The first library was constructed using S. fungicidicus wild-type genomic DNA. A partial genome scan was performed by endsequencing the inserts of 389 randomly selected clones using the universal T7 promoter primer. Eleven clones were identified as harbouring a portion of the enduracidin or other NRPS gene cluster. Both ends of these inserts were sequenced.

The second fosmid library was constructed using the pooled genomic DNA from S. fungicidicus strains with disrupted enduracidin NRPS genes. This library included approximately 60000 colonies and was plated onto LB agar medium containing Am $\left(100 \mathrm{mg} \mathrm{ml}^{-1}\right)$. Only 91 clones survived antibiotic selection. The fosmids were purified and the inserts were end-sequenced in order to find DNA segments that spanned gaps between positive fosmids in the first library.

A third library was constructed using wild-type genomic DNA and was divided into two portions of approximately 5500-6000 colonies. Each portion was screened by in situ hybridization. The first portion of the library was screened using a $5.8 \mathrm{~kb} \mathrm{BamHI}$ fragment from the left end of the pXYF24 insert and a fragment encoding a ThrA domain amplified by PCR. Forty positive colonies were obtained and 24 of these were randomly selected for end-sequencing. This allowed us to identify the extending inserts in fosmids pXYF103 and pXYF305. The second portion of this library was screened using a $2 \cdot 6 \mathrm{~kb}$ internal BamHI fragment from the pXYF305 insert. Thirty-one positive colonies were identified and 16 were end-sequenced, identifying fosmid pXYF607 which further extended the contiguous cloned region of DNA.

HPLC analysis of enduracidin production. Fermentation conditions for the production of enduracidin from wild-type S. fungicidicus ATCC 21013 and the disruptant strains SfPS18D17 and SfPS18D29 were as described by Higashide et al. (1968). For HPLC analysis, $60 \mathrm{~g}$ freshly harvested mycelia was washed with $120 \mathrm{ml}$ deionized water, resuspended in $120 \mathrm{ml}$ methanol and sonicated with a microprobe tip for $1 \mathrm{~min}$ at $15 \mathrm{~W}$. The mixture was shaken at 230 r.p.m. at $18^{\circ} \mathrm{C}$ for $3 \mathrm{~h}$ and then centrifuged at $2000 \mathrm{~g}$ for $20 \mathrm{~min}$. The supernatant was collected and evaporated to near dryness at $35^{\circ} \mathrm{C}$ under reduced pressure and resuspended in $10 \mathrm{ml} 90 \%$ methanol. The solution was adjusted to $\mathrm{pH} 4 \cdot 3$ with $1 \mathrm{M} \mathrm{HCl}$ and centrifuged at $2000 \mathrm{~g}$ for $20 \mathrm{~min}$. The supernatant was filtered through a $0.45 \mu \mathrm{m}$ syringe filter prior to analysis. HPLC was performed using a Gemini $\mathrm{C}_{18}$ column $(4.6 \times 150 \mathrm{~mm}, 5 \mu \mathrm{m}$; Phenomenex $)$ with isocratic elution in $30 \%$ acetonitrile and $70 \% 50 \mathrm{mM} \mathrm{NaH}{ }_{2} \mathrm{PO}_{4}, \mathrm{pH} 4 \cdot 5$, at a flow rate of $1.0 \mathrm{ml} \mathrm{min}^{-1}$. The UV region from $200-300 \mathrm{~nm}$ was scanned with a photodiode array detector; $267 \mathrm{~nm}$ was monitored with a variable wavelength detector.

Southern hybridization. S. fungicidicus genomic DNA was cleaved with restriction endonucleases, electrophoresed in $0.8 \%$ agarose gels 
and transferred onto Hybond-N nylon membranes (Roche). The manufacturer's protocol for colony lifts for in situ hybridization was followed. DNA probes were prepared using a digoxigenin-labelled system and hybridization was revealed using a digoxigenin-DNA detection kit (Roche).

DNA sequencing and analysis. Routine DNA sequencing of plasmids, PCR products, primer walking sequencing and fosmid insert end-sequencing was performed at the Oregon State University Center for Genome Research and Biocomputing (CGRB) using the AmpliTaq Dye-terminator Sequencing System (Perkin Elmer) and Applied Biosystems automated DNA sequencers (models 373 and 377). Fosmid DNA used for sequencing was prepared from $5 \mathrm{ml}$ induced LB culture with a QIAprep Spin Miniprep kit (Qiagen). Sequencing of the entire fosmid inserts at 10- to 20-fold coverage was performed by Macrogen (Seoul, South Korea). The nucleotide sequences were determined for both strands. Sequence analysis was carried out using the VectorNTI (Invitrogen) software package. Nucleotide and amino acid sequence similarity comparisons were carried out in public databases using the BLAST program (Altschul et al., 1990).

\section{RESULTS AND DISCUSSION}

\section{Cloning enduracidin biosynthesis gene probes}

NRPSs have highly conserved core motifs located in the A and peptidyl carrier protein (PCP) domains that permit the use of degenerate PCR primers to specifically amplify fragments of the NRPS genes (Marahiel et al., 1997). Using S. fungicidicus ATCC 21013 genomic DNA as template and a set of degenerate oligonucleotide primers targeted for regions encoding the A3 and PCP motifs, PCR yielded amplicons of the expected size (approx. $1 \cdot 2 \mathrm{~kb}$ ) which were cloned and sequenced. Five unique peptide synthetase (PS) probes were identified and designated sfPS5, sfPS9, sfPS11, sfPS15 and sfPS18. The standard in silico methods to predict A domain substrate specificity indicated that each of the cloned PS probes was expected to activate an amino acid found in enduracidin (Challis et al., 2000; Rausch et al., 2005; Stachelhaus et al., 1999).

Enduracidin contains 10 non-proteinogenic amino acid residues, including D- and L-enduracididine (End), Dand L-4-hydroxyphenylglycine (Hpg), 3,5-dichloro-L4-hydroxyphenylglycine (Dpg), L-citrulline (Cit) and D-ornithine (Orn) (Fig. 1). The genes directing Hpg biosynthesis in the chloroeremomycin pathway have been identified and their products characterized (Choroba et al., 2000; Hubbard et al., 2000; van Wageningen et al., 1998). Homologues of one of the genes, encoding PDH, are present in several other NRPS biosynthesis gene clusters (Chiu et al., 2001; Hojati et al., 2002; Li et al., 2004; Pootoolal et al., 2002; Sosio et al., 2003). To aid rapid identification of the enduracidin gene cluster, we also sought to amplify a specific $\mathrm{PDH}$ gene probe. Degenerate primers were designed from conserved regions identified in PDHs from other NRPS gene clusters and used to amplify a $0.5 \mathrm{~kb}$ PCR product from S. fungicidicus genomic DNA. The PCR product was cloned into pGEM-T easy vector to yield pGEMTE-sfPhd-Nt.
Sequence analysis confirmed that it encoded the N-terminal portion of a putative $\mathrm{PDH}$.

\section{Inactivation of the sfPS11-, sfPS15- and SfPS18- containing NRPS genes}

To provide direct evidence that the genes corresponding to the PCR-amplified probes are involved in enduracidin biosynthesis, probes correlating to Thr- (sfPS11), Hpg(sfPS15) and Asp-activating (sfPS18) A domains were used for gene disruption by single- or double-crossover homologous recombination. Gene disruption constructs were made by introducing the $\mathrm{Am}^{\mathrm{R}}$ marker into sfPS11, sfPS15 and sfPS18, carried in the pGEM-T vector. These aac(3)IVcontaining inserts were then transferred into the Streptomyces-E. coli temperature-sensitive conjugal shuttle vector pXY300 (Yin et al., 2003). The three gene disruption constructs, pXY300-sfPS11-Am ${ }^{\mathrm{R}}$, pXY300-sfPS15-Am ${ }^{\mathrm{R}}$ and pXY300-sfPS18-Am ${ }^{R}$, were separately introduced into $S$. fungicidicus by intergeneric conjugation (Kieser et al., 2000). Independent double-crossover disruptants obtained with pXY300-sfPS18-Am ${ }^{\mathrm{R}}$ (Fig. 2a) were confirmed by Southern blot analysis of the chromosomal DNA (Fig. 2b) and later by sequencing the insert of disrupted fosmid pXYFD16. The loss of enduracidin production from the double-crossover mutant strains SfPS18D17 and SfPS18D29 was confirmed by HPLC (Fig. 2c).

Southern blot analysis revealed that constructs pXY300-

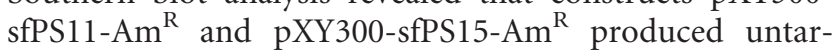
geted disruptants (SfPS11D9, SfPS15D12 and SfPS15D31) through partial homologous recombination (data not shown). These results are not surprising because sfPS11 exhibits $96 \%$ identity over 879 nt with the DNA sequence encoding the $\mathrm{Ser}^{12}$-activating $\mathrm{A}$ domain from the end cluster. Likewise, six Hpg/Dpg-activating A domains in the end cluster, including module 17 corresponding to sfPS15, share $78-90 \%$ identity over $879 \mathrm{nt}$. Inactivation of the enduracidin Ser ${ }^{12}$-activating A domain via single-crossover partial homologous recombination was also confirmed by sequencing the insert of the disrupted fosmid pXYFD18. HPLC analysis indicated that these disruptants also lost the ability to produce enduracidin (data not shown).

\section{Cloning and sequencing the enduracidin biosynthetic gene cluster}

Construction of a wild-type fosmid library. The first fosmid genomic library was constructed from S. fungicidicus wild-type chromosomal DNA. The structural similarity of enduracidin and ramoplanin and the availability of the sequenced ramoplanin gene cluster allowed us to conduct a partial genome scan to identify fosmid inserts with ends homologous to genes expected for enduracidin biosynthesis. Eleven clones were identified with NRPS genes or sequence similar to genes in the ramoplanin cluster. Three fosmids, pXYF24, pXYF148 and pXYF200, were selected for further analysis. Restriction and Southern blot analysis indicated that pXYF24 overlaps pXYF148, but 
(a)

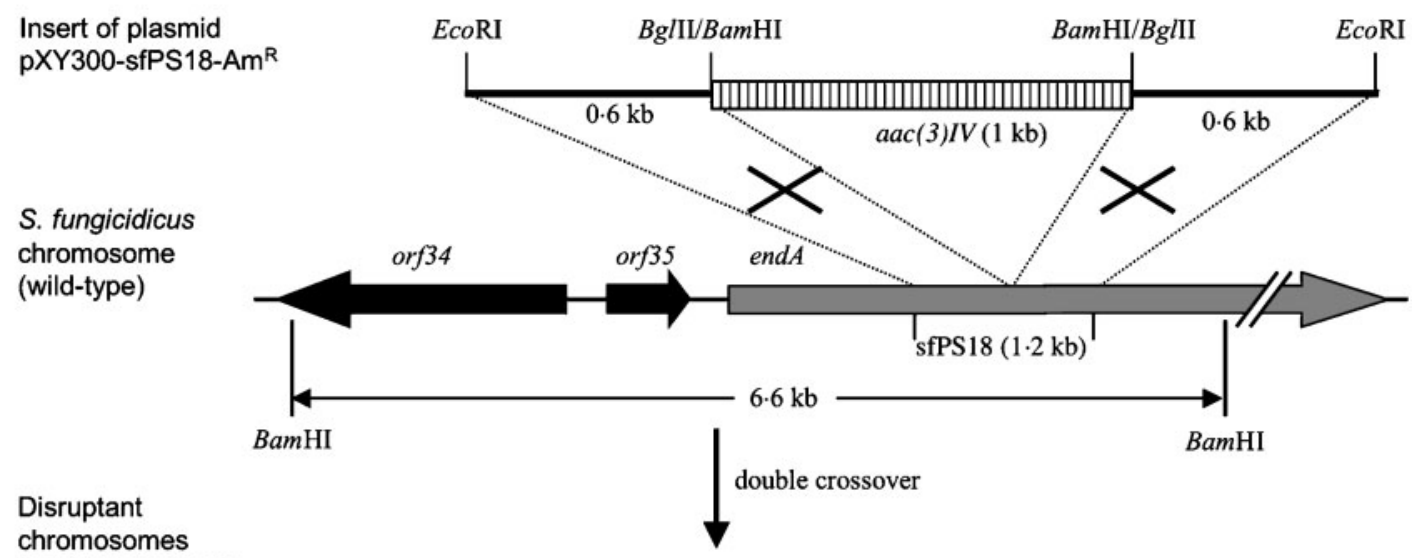

SfPS18D17 \& D29 orf34 orf35 endA (disrupted)

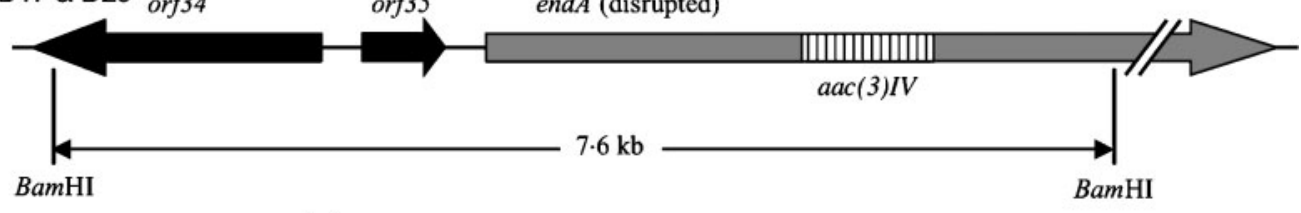

(b)

(c)
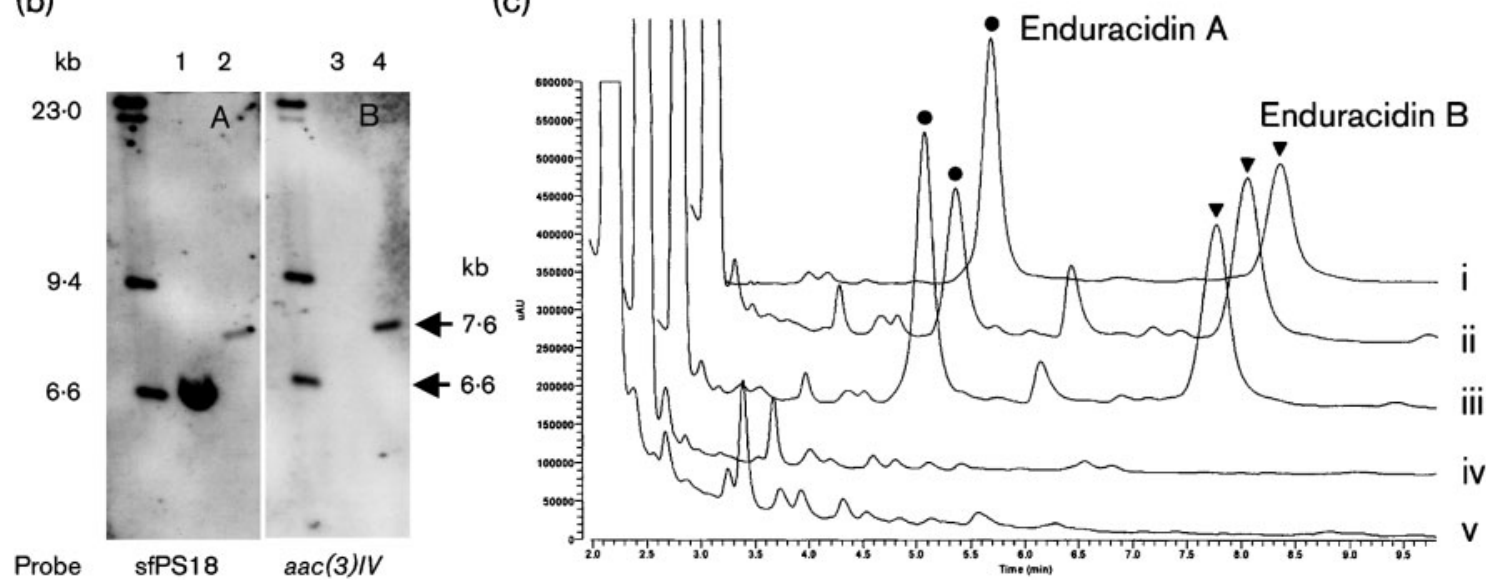

Fig. 2. Inactivation of the enduracidin biosynthetic gene cluster and metabolite analysis. (a) Insertion of the $A m^{R}$ marker aac(3)IV into the sfPS18 A domain region of endA via double-crossover homologous recombination. (b) Southern blot analysis of wild-type S. fungicidicus (lanes 1 and 3) and disruptant (SfPS18D29) genomic DNA digested with BamHI. Blot A was probed with DIG-labelled SfPS18 and blot B was probed with DIG-labelled aac(3)IV. (c) HPLC analysis of enduracidin production by $S$. fungicidicus wild-type and mutant strains. (i) Enduracidin A and B standards; (ii) methanolic extract of wildtype mycelia; (iii) co-injection of wild-type extract and standards; (iv and v) methanolic extract of S. fungicidicus disruptant strains SfPS18D17 and SfPS18D29.

neither of them overlaps pXYF200. One end of pXYF200 encodes an Hpg-activating A domain and an incomplete thioesterase domain, suggesting this segment should be near the end of the clustered NRPS genes.

Construction of a disruptant fosmid library. A second library was constructed using mixed genomic DNA prepared from the five strains with inactivated enduracidin NRPS genes. The aim was to use a positive selection strategy to find fosmids that would connect pXYF148 to
pXYF200 and also extend the region located downstream of the thioesterase end of pXYF200. Because we showed the $\operatorname{aac}(3) I V$ gene was inserted into the enduracidin cluster in these strains, clones in this library that survive antibiotic selection must harbour a fragment of the targeted cluster. A total of $91 \mathrm{Am}^{\mathrm{R}}$ clones were identified. Restriction fragment length analysis and additional sequence from primer walking and subcloning identified two disrupted fosmids, pXYFD16 and pXYFD18, that connected pXYF148 with pXYF200. With these fosmids, we could construct an 
overlapping fosmid insert map covering approximately $100 \mathrm{~kb}$ (Fig. 3a).

Construction and screening of a second wild-type genomic library. Fosmids extending the contiguous segment of the chromosome beyond the ends of pXYF24 and pXYF200 were not identified in either the original wildtype or the disruptant library. Therefore, we constructed and screened a second $S$. fungicidicus wild-type genomic library. The new library was divided into two portions and each was screened by in situ hybridization. The first portion was screened using a fragment from the left end of the pXYF24 insert and a fragment encoding an NRPS A domain predicted to activate Thr. This allowed us to identify fosmid pXYF103, which overlaps with and extends $15 \mathrm{~kb}$ beyond the left end of pXYF24, and fosmid pXYF305, which overlaps with and extends $14 \mathrm{~kb}$ beyond the right end of pXYF200 (Fig. 3a).

The second portion of this library was screened using an internal BamHI fragment from the pXYF305 insert. Fosmid pXYF607 was identified which overlaps with and extends $15 \mathrm{~kb}$ beyond the right end of pXYF305. In all, eight overlapping fosmid inserts were identified which span approximately $148 \mathrm{~kb}$ of contiguous DNA on the $S$. fungicidicus chromosome. The inserts from fosmids pXYF24, pXYF148, pXYFD16, pXYFD18 and pXYF200 were completely sequenced and that of pXYF305 was partially sequenced, covering a $116 \mathrm{~kb}$ region that harbours the entire enduracidin (end) biosynthetic gene cluster (Fig. 3b).

\section{Overall analysis of the enduracidin (end) biosynthetic gene cluster}

The end gene cluster resides on an $84 \mathrm{~kb}$ segment of the S. fungicidicus chromosome and includes 25 ORFs (orf 22 to orf46). The predicted function for each ORF was assigned by comparing the translated product with known proteins in public databases (Table 1). Genes identified include those required for the formation of the lipid and nonproteinogenic amino acid precursors, assembly of the peptide backbone, export and regulation of enduracidin biosynthesis. Twenty-one ORFs exhibited significant similarity with counterparts in the ramoplanin cluster (Table 1). The probable boundaries of the end cluster were established by comparison with the ramoplanin gene cluster and from the deduced functions of the end and flanking gene products.

\section{Analysis of the enduracidin NRPSs}

Four peptide synthetases, designated EndA, EndB, EndC and EndD, assemble the 17-residue enduracidin peptide backbone. The organization of the modules and domains in these four proteins is shown in Fig. 4 and, in general, follows the NRPS collinearity principle (Marahiel et al., 1997). The most immediately notable features are a missing A domain from module 8 in EndB that should incorporate L-allo-Thr ${ }^{8}$, and EndD which is a single-module NRPS with a unique Nterminal region and an A domain predicted to activate Thr. The other modules and domains exhibit typical NRPS features, and the predicted substrate for the A domain of each module correlated with the residue expected based on

(a)

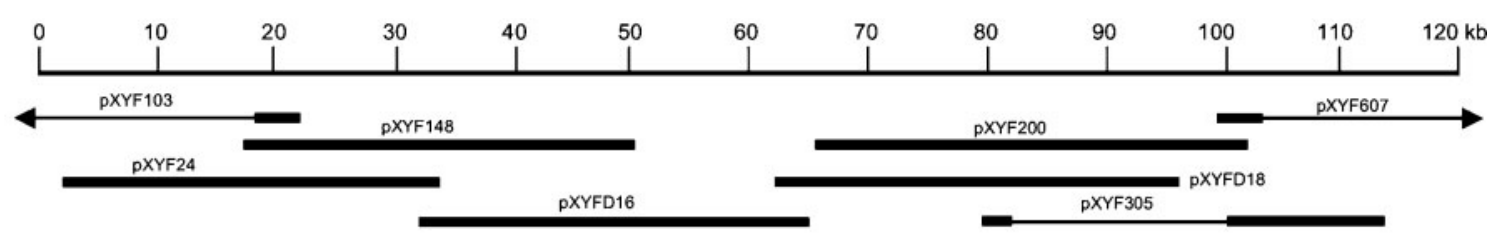

(b)

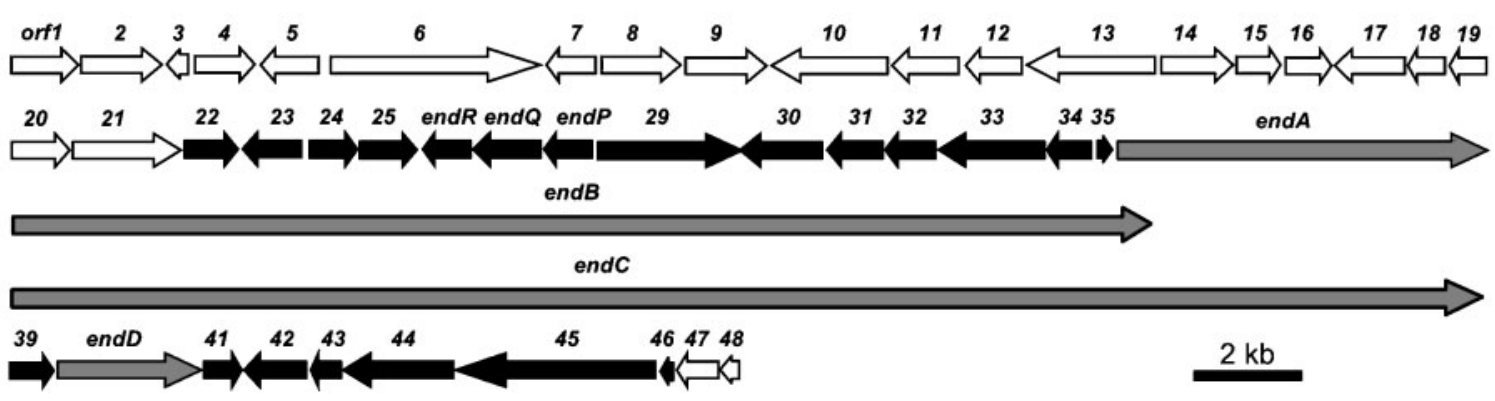

Fig. 3. (a) Overlapping fosmid inserts cloned from the $S$. fungicidicus genome that harbours the enduracidin biosynthetic gene cluster. Thick lines represent the $116 \mathrm{~kb}$ region that was fully sequenced. Arrows indicate where the insert extends beyond the $120 \mathrm{~kb}$ scale shown. (b) Organization of the sequenced end cluster (filled arrows) and flanking regions (white arrows). Grey arrows represent the NRPS genes. 
Table 1. Summary of ORFs identified in the enduracidin gene cluster and flanking regions

The organization of the end cluster is shown in Fig. 3(b). Size indicates the number of amino acids in the translated product. Homologues found in the related ramoplanin biosynthetic gene cluster are presented separately from the best matching protein identified by BLAST analysis.

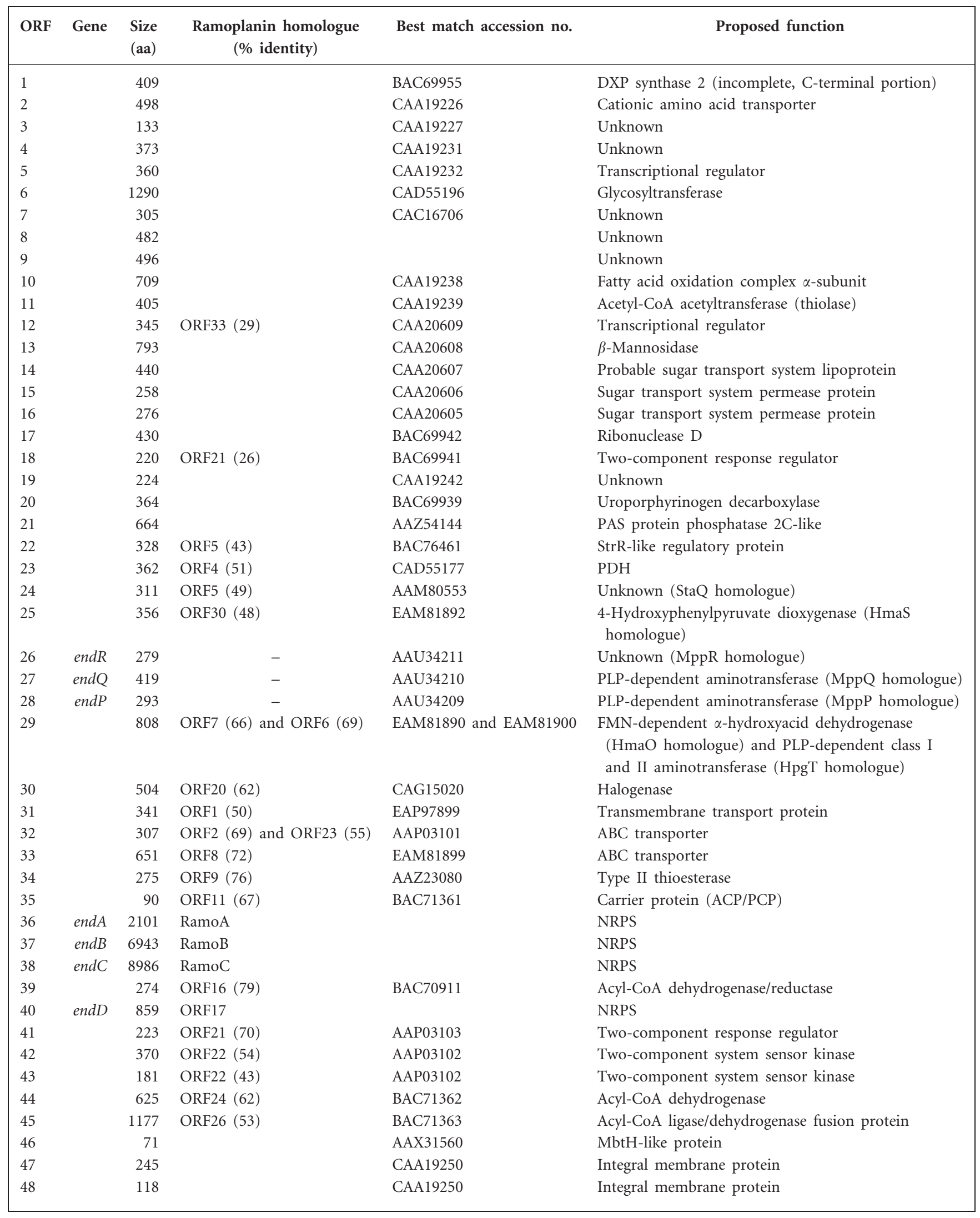


the collinearity rule (Table 2). The NRPS substrate-binding pocket databases do not contain signature sequences for citrulline (L-Cit, module 9) or enduracididine ( $\mathrm{D}$ - and LEnd, modules 10 and 15, respectively). Interestingly, the same A domain substrate recognition sequence, DFWSVGMV, is found in modules incorporating $\mathrm{L}-\mathrm{Thr}^{2}$ (EndA-m2), D-allo-Thr ${ }^{5}$ (EndB-m3) and L-allo-Thr ${ }^{8}$ (EndD). EndA-m2 and EndB-m3 are both predicted to recognize L-Thr as substrate and, accordingly, the regions between core motifs A4 and A5 that define much of the substrate-binding pockets of the A domains are identical at the amino acid level. The A domain of EndD is expected to recognize the rare L-allo diastereomer of $\mathrm{Thr}$, so it is surprising that the same 8 substrate-specifying residues are shared with EndA-m2 and EndB-m3. However, the A4-A5 region of EndD shares only $59 \%$ identity with that of EndA$\mathrm{m} 2$ and EndB-m 3 and is 3 residues longer, allowing for differences that could discriminate between L-Thr and Lallo-Thr. Also, the location of EndC-m3 corresponds to the incorporation of $\mathrm{D}-\mathrm{Ser}^{12}$, but the substrate recognition sequence, DVWSVAMV, most closely resembles Thrincorporating A domains and shows moderate similarity to Ser A domains (DVWHVSLI) from the Pseudomonas fluorescens Pf-5 pyoverdin synthetase (Paulsen et al., 2005). Interestingly, the corresponding amino acid in ramoplanin is D-allo-Thr and the deduced substrate specificity sequence for the ramoplanin module 12 A domain is DFWSVGMV. The presence of a Phe in the second position of the substrate specificity sequence has been suggested to be a key factor for Thr recognition and Phe is found at this position in all three enduracidin synthetase Thr A domains (Table 2) (Challis et al., 2000). Inspection of the endC and ramoC sequence encoding this residue reveals a GTC in endC and a TTC in ramoC. The mutation changes the Val codon GUC to the Phe codon UUC (or vice versa) and accounts for the switch in substrate specificity from Ser to Thr by the respective peptide synthetases. Finally, the A domain in the 3,5dichloro-L-4-hydroxyphenylglycine (Dpg) module shares the same substrate specificity sequence, DAYHLGLL, as four of the Hpg A domains, suggesting that chlorination of Hpg to yield the Dpg residue occurs on an NRPS-bound species or the nascent peptide, rather than at the free amino acid stage.
Enduracidin assembly presumably begins with EndA, predicted to be a 2101 aa $(224 \mathrm{kDa})$ two-module NRPS with an $\mathrm{N}$-terminal condensation domain (EndA-C1) similar to those found in other lipopeptide-loading modules proposed to accept a lipid substrate from an acyl carrier protein (Duitman et al., 1999). These have been referred to as $\mathrm{C}^{\mathrm{III}}$ domains and examples are found in the ramoplanin, CDA and daptomycin systems (Miao et al., 2005, 2006). EndA-C2 then couples N-lipo-L-Asp ${ }^{1}$ and L-Thr ${ }^{2}$ to form a dipeptide that is transferred to EndB (6943 aa, $741 \mathrm{kDa})$. EndB is composed of seven modules, but as noted above, it is missing an A domain from module 8 (EndB-m6). EndD is a single-module NRPS ( $859 \mathrm{aa}, 91 \mathrm{kDa}$ ) with an A domain predicted to activate Thr and a PCP domain. Preceding the A domain is an $\mathrm{N}$-terminal region of approximately 280 aa that shares weak homology with NRPS C domains. Presumably, EndD activates and tethers L-allo-Thr to the PCP domain and the $\mathrm{N}$-terminal domain directs the protein-protein interaction for the transfer of L-allo-Thr to module 8 (EndB$\mathrm{m} 6$ ). Similar proposals are suggested for syringomycin and ramoplanin biosynthesis (Guenzi et al., 1998; McCafferty et al., 2002). EndB, with the possible participation of EndD, then catalyses the peptidyl chain elongation from amino acid residue L-Thr ${ }^{2}$ to L-Cit ${ }^{9}$. Experimental confirmation of the function of the $\mathrm{N}$-terminal portion of EndD and proof of in trans loading of EndB remains to be determined. EndC is the final NRPS (8986 aa, $955 \mathrm{kDa}$ ) and consists of eight modules and catalyses the peptidyl chain extension from amino acid residues D-End ${ }^{10}$ to $\mathrm{L}-\mathrm{Hpg}^{17}$, and terminates with a thioesterase (TE) domain that promotes the cyclization and release of the peptide.

\section{Analysis of the PCP domains}

There are 18 thiolation $(\mathrm{T})$ or PCP domains in the four enduracidin synthetases. Conceptually, 17 PCP domains are sufficient for enduracidin assembly. The extra PCP domain occurs because of the proposed transfer of L-allo-Thr from EndD to EndB-m6 (module 8). The exact mechanism of the substrate transfer between these NRPSs is unknown at present. One possibility is that the EndB-m6 PCP is redundant or nonfunctional and the $\mathrm{C}$ domain of EndB-m7 directly condenses the L-allo-Thr on EndD with the L-Cit residue bound to the EndB-m7 PCP. The C domain of EndB-m6 could couple the

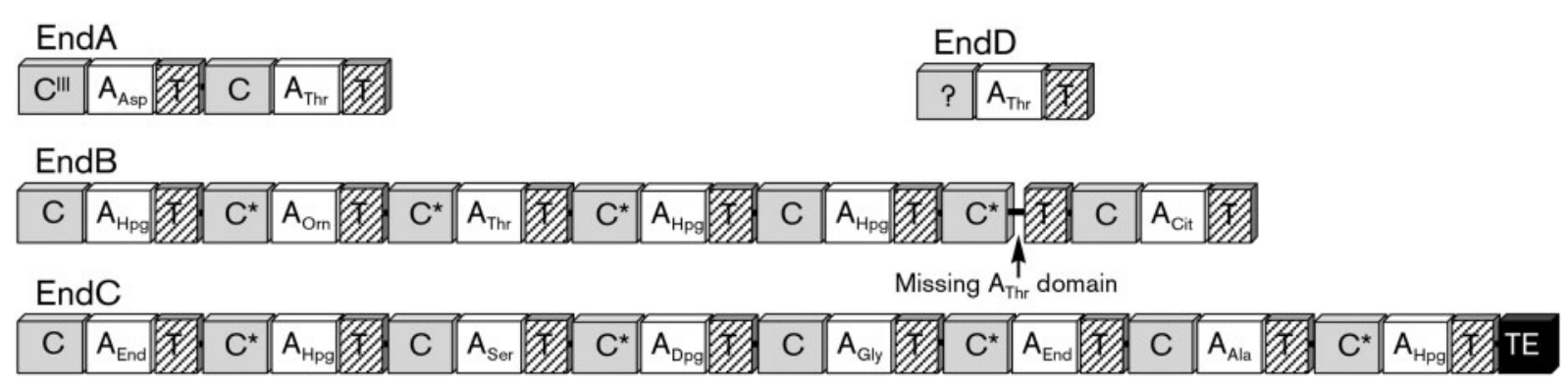

Fig. 4. Module and domain organization of the enduracidin NRPSs. Proposed dual function condensation/epimerization domains are indicated with $\mathrm{C}^{*}$. 
Table 2. Derived substrate signature sequences for NRPS adenylation domains identified in the enduracidin cluster

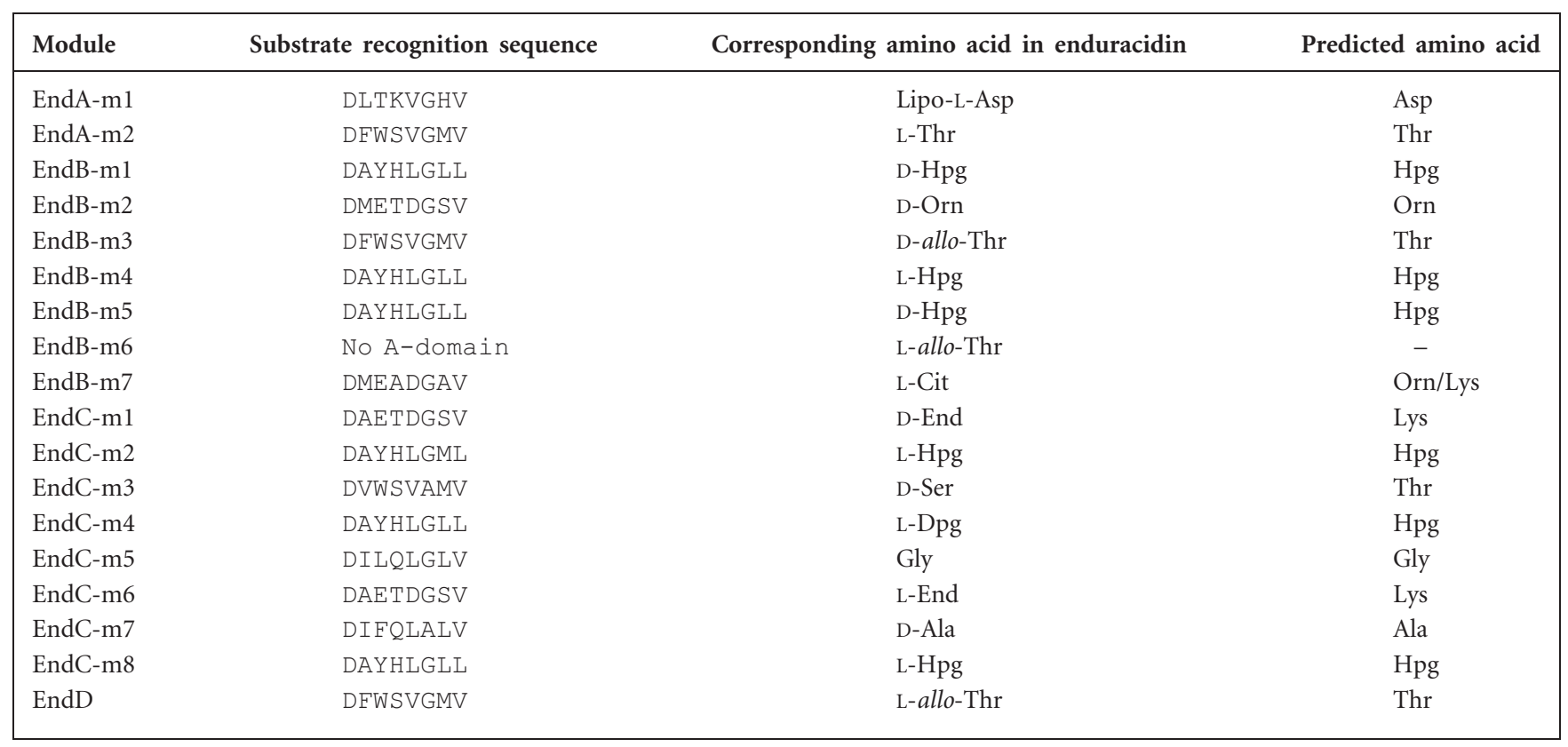

resulting dipeptide on EndB-m7 with the peptidyl species attached to EndB-m5, allowing normal peptide assembly to continue. Alternatively, EndD could transfer the tethered L-allo-Thr directly to the PCP of EndB-m6, but a PCP to PCP transfer may require the action of a separate acyltransferase (Vaillancourt et al., 2005). Interestingly, the PCP domain core motif found in both EndD and EndB-m6 is LGGNSL. The occurrence of an Asn residue preceding the Ser to which the $4^{\prime}$-phosphopantetheine arm is attached is rarely observed. For PCP domains that accept L-amino acids, T(L) domains, the core motif is LGGDSI, whereas for PCP domains that are associated with epimerization (E) domains and accept Damino acids, T(D) domains, the consensus core motif is XGGHSL (Linne et al., 2001). The corresponding PCP domains in the ramoplanin synthetases also have an Asn residue in the core motif. Table 3 correlates the PCP domains in the enduracidin synthetases with the respective modules and corresponding substrate amino acids. With the exception of EndB-m6 and EndD discussed above, all enduracidin synthetase PCP domains are of the T(1) type. This is consistent with the lack of $\mathrm{E}$ domains in the enduracidin synthetases, but does not correlate with occurrence of $7 \mathrm{D}$-amino acids in the peptide product. Interestingly, analysis of the translated products of NRPS genes from the actinomycete Nocardia farcinica IFM10152 reveals the core motifs of the PCP domains primarily contain Asn instead of Asp or His (Ishikawa et al., 2004). The role of the rare Asn residue in the PCP domains remains to be elucidated.

\section{Origination of the D-amino acid residues in enduracidin}

Enduracidin contains 7 D-amino acids but the megasynthetase contains no epimerization (E) domains and there were no racemase or epimerase genes detected in the sequenced region of the S. fungicidicus chromosome. This unusual situation has previously been observed in Pseudomonas peptide synthetases assembling the lipopeptides syringomycin (Guenzi et al., 1998), syringopeptin (ScholzSchroeder et al., 2003) and arthrofactin (Roongsawang et al., 2003). Ramoplanin synthetase is the only other actinomycete NPRS we are aware of that shares this feature (McCafferty et al., 2002). It was suggested that the epimerization function required for the biosynthesis of syringomycin may be provided in trans by external amino acid racemase(s) (Guenzi et al., 1998). Biochemical analysis of recombinant A domains from these systems demonstrated that they preferentially activate L-amino acids even when the excised A domain correlates with the position of a D-amino acid in the peptide product (Guenzi et al., 1998; Recktenwald et al., 2002; Roongsawang et al., 2003; Trauger \& Walsh, 2000). This discrepancy was recently resolved when Balibar et al. (2005) demonstrated that the D-amino acids in arthrofactin are generated on the surface of the NRPS by dual function C/E domains.

The formation of $\mathrm{D}$-amino acid residues in enduracidin possibly involves the same mechanism demonstrated for arthrofactin. The $\mathrm{C}$ domains in both peptide assembly lines that are immediately downstream of modules corresponding to D-amino acids share 50-60\% overall amino acid identities and are clearly distinct from the more typical C domains following L-amino acid modules (Fig. 5). The studies by Balibar et al. (2005) also revealed that epimerization of the donor peptidyl-S-enzyme species only occurred when the adjacent downstream acceptor aminoacyl-S-enzyme species was present. This is relevant to the in trans loading of EndB-m6 discussed above because this 
Table 3. Comparison of conserved core motifs in the PCP domains of enduracidin synthetases

\begin{tabular}{|c|c|c|}
\hline Module & PCP domain core motif region & Corresponding amino acid \\
\hline EndA-m1 & DDDFFALGGHSLPATR & Lipo-L-Asp \\
\hline EndA-m2 & DDDFFALGGHSLLATR & L-Thr \\
\hline EndB-m1 & EDDFFALGGHSLLAVS & D-Hpg \\
\hline EndB-m 2 & DDDFFALGGHSLLVVS & D-Orn \\
\hline EndB-m3 & DDDFFALGGHSLLAVS & D-allo-Thr \\
\hline EndB-m4 & DDDFFLLGGHSLLAMR & L-Hpg \\
\hline EndB-m5 & EDDFFALGGHSLLAVS & D-Hpg \\
\hline EndB-m6 & DDDFFALGGNSLVATR & L-allo-Thr \\
\hline EndB-m7 & DDHFFALGGHSLLATR & L-Cit \\
\hline EndC-m 1 & EDDFFALGGHSLLAVS & D-End \\
\hline EndC-m 2 & DDDFFTLGGHSLLVTR & L-Hpg \\
\hline EndC-m3 & DDDFFALGGHSLLAVS & D-Ser \\
\hline EndC-m4 & DDDFFAKGGHSLLATV & L-Dpg \\
\hline EndC-m5 & DDDFFALGGHSLLAVS & Gly \\
\hline EndC-m6 & DDDFFALGGHSLLATR & L-End \\
\hline EndC-m7 & DDDFFALGGHSLLAVS & D-Ala \\
\hline EndC-m8 & DDDFFALGGHSLLAVR & L-Hpg \\
\hline EndD & SDSFWELGGNSLLAVR & L-allo-Thr \\
\hline
\end{tabular}

module possesses a $\mathrm{C} / \mathrm{E}$ domain that should epimerize the Hpg residue on EndB-m5. The necessity of having the downstream PCP module loaded for epimerization to occur may support a loading mechanism wherein the L-allo-Thr tethered to EndD is directly transferred to the PCP of EndB-m6.

\section{Biosynthesis of non-proteinogenic amino acids}

The biosynthesis of Hpg has been elucidated by biochemical analysis of recombinant enzymes from the chloroeremomycin pathway (Choroba et al., 2000; Hubbard et al., 2000; van Wageningen et al., 1998). The process requires four gene products: $\mathrm{PDH}, 4$-hydroxymandelic acid synthase (HmaS), 4-hydroxymandelic acid oxidase (HmaO) and 4hydroxyphenylglycine aminotransferase (HpgT). Orf23 and Orf25 are homologues of PDH and HmaS, respectively, and orf29 apparently encodes an HpgT/HmaO fusion protein. In addition to orf23, S. fungicidicus possesses another $\mathrm{PDH}$ gene located outside the end cluster that is presumably involved in normal aromatic amino acid biosynthesis. A portion of this second PDH gene was amplified by PCR and comparison of the available translated sequence (168 aa) with Orf23 showed that this region shared $61 \%$ identity. Inactivation of the second $\mathrm{PDH}$ gene had no effect on enduracidin production (data not shown).

The unusual organization of the $h m a O$ and $h p g T$ homologues in a single ORF in the end cluster was reconfirmed by double-strand sequencing of multiple fosmid templates. $\mathrm{HmaO}$ and HpgT catalyse sequential reactions in the generation of Hpg and the fusion protein may lead to more efficient production of Hpg inasmuch as it contributes to 6 of the 17 amino acid residues in enduracidin. In the

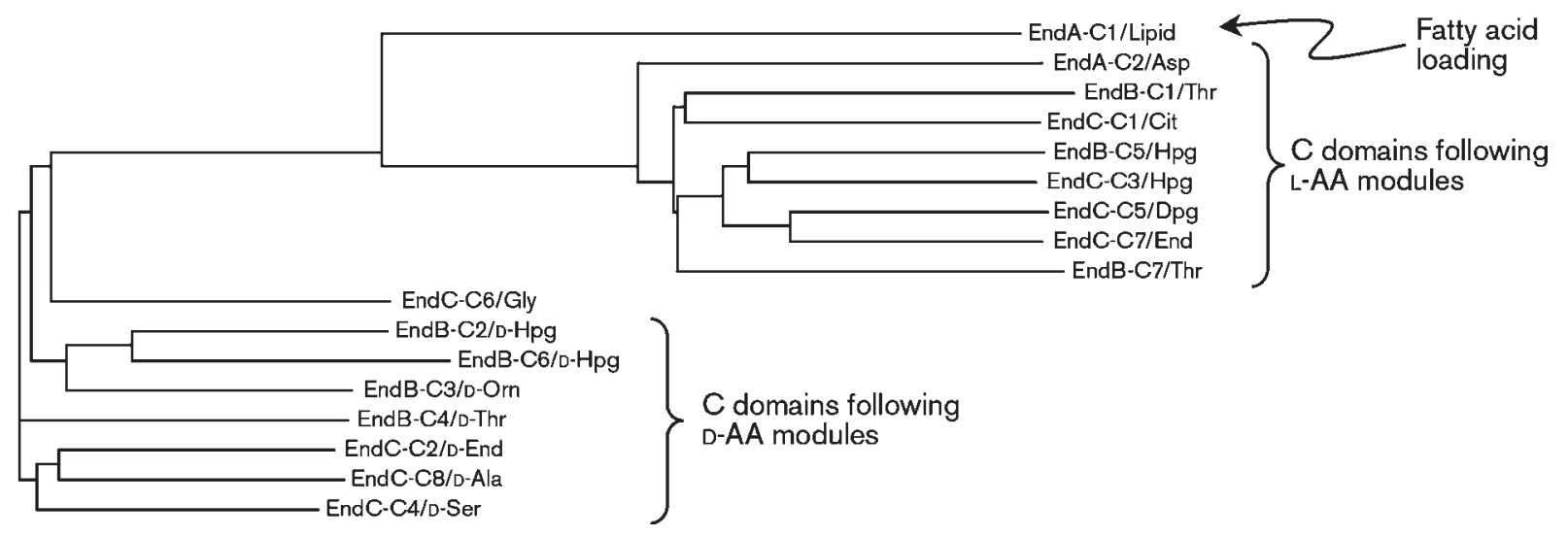

Fig. 5. Phylogram of enduracidin synthetase condensation domains. 
chloroeremomycin (van Wageningen et al., 1998), balhimycin (Recktenwald et al., 2002) and teicoplanin (Li et al., 2004) clusters, $h m a S$ and $h m a O$ are organized in a two-gene operon and, in the CDA cluster, $h m a O$ and $h p g T$ form an operon (Hojati et al., 2002). Although the genes encoding HpgT and $\mathrm{HmaO}$ are adjacent in the ramoplanin cluster, there is no operon organization observed among the HpgT-, HmaOand HmaS-encoding genes (McCafferty et al., 2002).

Little is known about the formation of the rare D- and L-End residues other than they originate from L-Arg (Hatano et al., 1984). The mannopeptimycins, isolated from a strain of $S$. hygroscopicus, contain D- and L- $\beta$-hydroxyenduracididine ( $\beta$-OHEnd) residues and are the only other peptide antibiotics we are aware of that contain this unusual amino acid (He et al., 2002). Both the mannopeptimycin ( $m p p$, accession no. AY735112) and end clusters contain a three-gene operon, $m p p P Q R$ and $e n d P Q R$, respectively, that share very high identity (Fig. 6). Given that End and $\beta$ OHEnd are the only non-proteinogenic amino acids common to mannopeptimycin and enduracidin, the products of these three genes are proposed to direct End biosynthesis. The gene immediately upstream of the $m p p P Q R$ operon, $m p p O$, has a translated product that is homologous to VioC, a non-haem iron, 2-oxoglutaratedependent oxygenase that catalyses the formation of $2 S$ hydroxy-L-Arg from L-Arg (Yin \& Zabriskie, 2004). We and others have shown that VioC and the pyridoxal phosphatedependent enzyme VioD act in tandem to form the $2 S, 3 R$ capreomycidine residue found in the peptide antibiotic viomycin (Ju et al., 2004; Yin et al., 2004). Through gene disruption experiments and biochemical characterization of recombinant $\mathrm{MppO}$, we have shown that this enzyme hydroxylates the $\beta$-position of L-End and does not generate a precursor for cyclization of the Arg side chain (Haltli et al., 2005). The fact that $\mathrm{MppO}$ is not involved in L-End formation is consistent with absence of an $m p p O$ homologue in the end cluster.

Questions remain regarding the formation of L-End in both the mannopeptimycin and enduracidin pathways. Routes to enduracididine can be proposed that are analogous to the formation of capreomycidine by VioD, and rely on the putative PLP-dependent enzymes EndP and/or EndQ to catalyse elimination/replacement reactions beginning with either $\beta$-hydroxy or $\gamma$-hydroxyarginine. However, we identified no genes in the sequenced regions of the S. fungicidicus chromosome predicted to encode a hydroxylase or similar enzyme. Similarly, the only hydroxylase gene located in the $m p p$ cluster is $m p p O$. The respective function of EndP and EndQ, and the role of EndR, which exhibits some similarity to acetoacetate decarboxylases, will probably require in vitro analysis of the recombinant proteins in combination with in vivo analysis of disruption and complementation mutants. Attempts to date to express these genes in E. coli have only yielded insoluble protein.

The other two non-proteinogenic amino acids in enduracidin are ornithine and citrulline. Genes directing the synthesis of these compounds were not expected in the cluster inasmuch as these amino acids are normally found in the bacterial cell as intermediates in arginine metabolism.

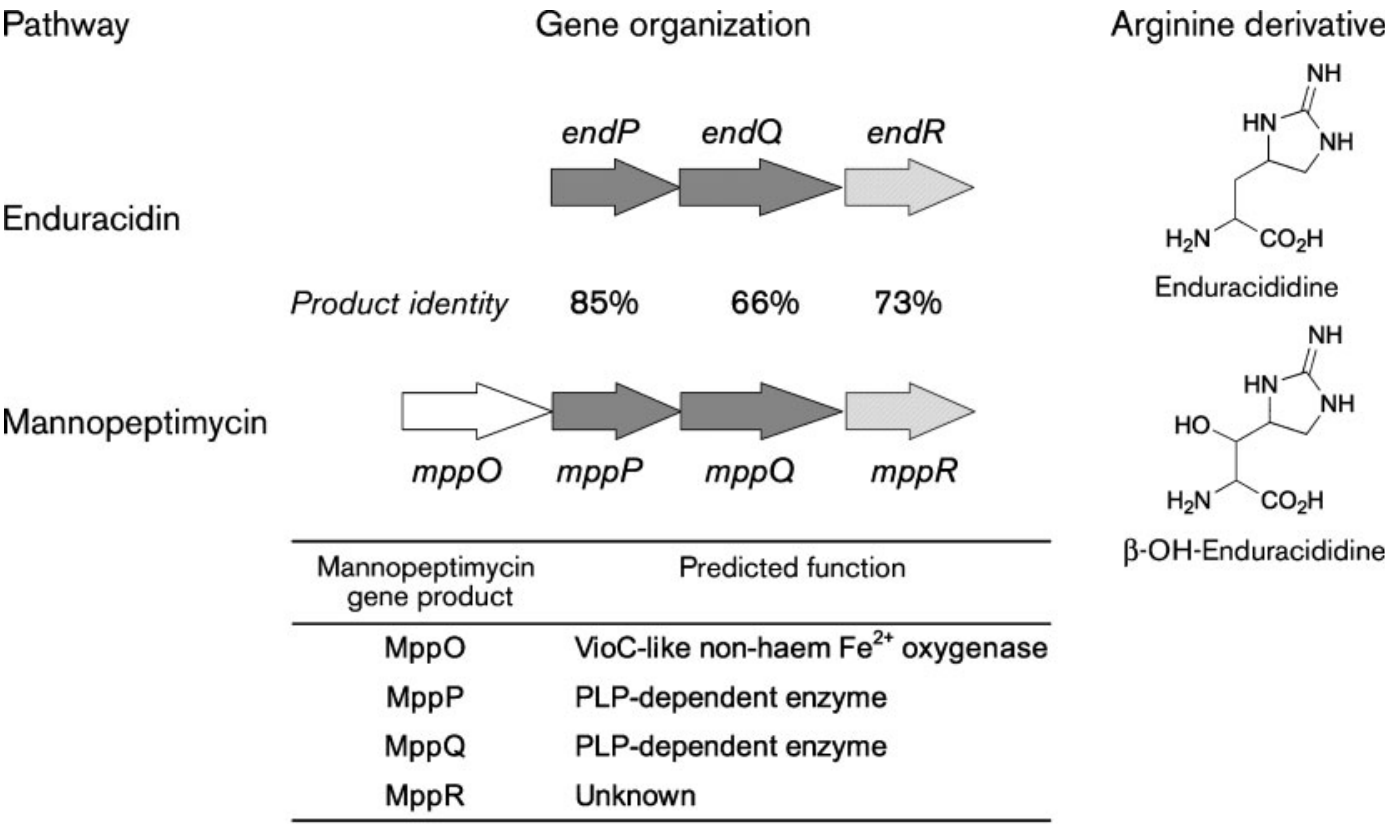

Fig. 6. Relationship and organization of the $m p p P Q R$ and endPQR operons. 


\section{Formation and attachment of the fatty acid tail}

Enduracidins A and B differ only in the fatty acid side chain attached to the starter Asp unit (Iwasaki et al., 1973). Four gene products, Orf35, Orf39, Orf44 and Orf45, are predicted to activate and modify a precursor fatty acid and transfer it to the amine of Asp ${ }^{1}$ on EndA (Fig. 7). Counterparts of these proteins are found in the ramoplanin pathway, which incorporates a shorter, but similar, $2 Z, 4 E$ unsaturated lipid (cf. Fig. 1 and Table 1). However, Orf45 from the end pathway appears to be a fusion protein consisting of an acyl-CoA ligase and an acyl-CoA dehydrogenase. In the ramoplanin cluster orf26 encodes an acyl-CoA ligase and orf 24 and orf 25 encode homologous acyl-CoA dehydrogenases (McCafferty et al., 2002).

We expect the dehydrogenase function of Orf45 introduces the first double bond in the fatty acid and then Orf39 and/or Orf44 participate in the second dehydrogenation and double-bond isomerization. Recently, an acyl-CoA dehydrogenase in the friulimicin pathway was shown to be involved in the formation of the $\Delta c i s 3$ double bond in the lipid side chain of that lipopeptide (Heinzelmann et al., 2005). Transfer of the modified fatty acid to the carrier protein Orf35 facilitates acylation of the Asp residue on EndA. It is also possible that Orf35 accepts an intermediate species that is further modified as the carrier protein-bound substrate rather than as a coenzyme A adduct.

\section{Chlorination of 4-hydroxyphenylglycine}

The deduced product of orf 30 shows at least $69 \%$ amino acid identity to several halogenases associated with various glycopeptide biosynthesis pathways and is predicted to carry out the chlorination of $\mathrm{Hpg}^{13}$ to form 3,5-dichloro-L-4hydroxyphenylglycine (Dpg) (Li et al., 2004; Pootoolal et al., 2002; Recktenwald et al., 2002; van Wageningen et al., 1998). orf30 encodes the only halogenase in the end cluster, suggesting that both chlorine atoms in the Dpg residue are introduced by a single enzyme. Similarly, complestatin contains two Dpg residues and the gene cluster only contains a single halogenase gene, $c 0 m H$ (Chiu et al., 2001). In balhimycin biosynthesis, one halogenase introduces two chlorine atoms at different positions of the glycopeptide antibiotic (Puk et al., 2002). PltA, an $\mathrm{FADH}_{2}$-dependent halogenase involved in pyoluteorin biosynthesis, has been shown to catalyse the dichlorination of a carrierprotein-bound pyrrole species (Dorrestein et al., 2005). These $\mathrm{FADH}_{2}$-dependent halogenases required an NADHdependent flavin reductase for cofactor recycling and twocomponent systems have been characterized that generate 7-chlorotryptophan during rebeccamycin and pyrrolnitrin biosynthesis (Keller et al., 2000; Yeh et al., 2005). A flavin reductase gene has not been identified near the enduracidin biosynthetic genes.

The timing of chlorination has not been determined but the substrate specificity sequence for the A domain of module 13 (EndC-m4), which corresponds to Dpg, is identical to the<smiles>COS(=O)(=O)C(=O)/C=C/CCCCCCC(C)C</smiles>
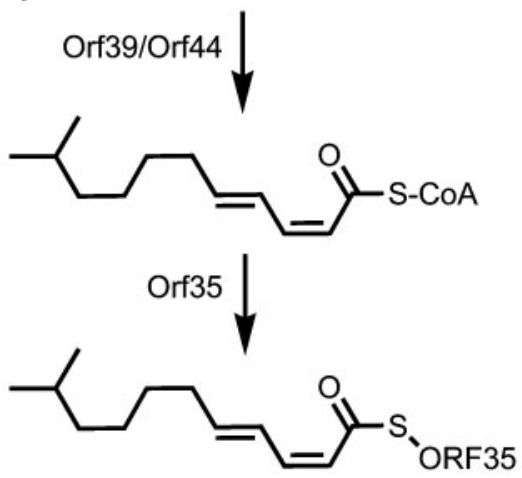

EndA

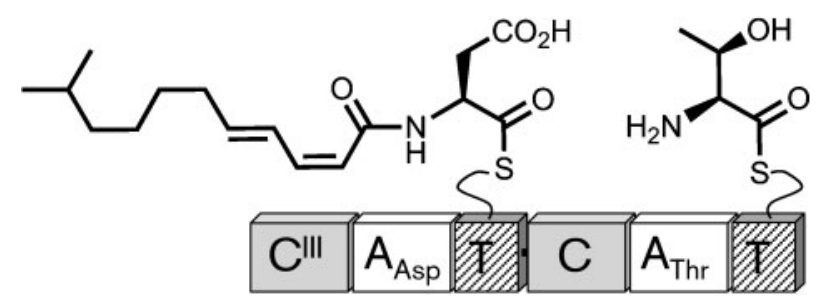

Fig. 7. Proposed activation, modification and attachment of the lipid tail of enduracidin A.

substrate specificity sequences deduced for four A domains predicted to activate Hpg (Table 2). Therefore, it would seem unlikely that free L-Hpg is chlorinated by Orf30 and the resulting Dpg is directly incorporated by the NRPS. Given the lack of additional A domain/carrier protein genes and the fact that EndC-m4 appears to be a functional module, we expect halogenation to occur on an NRPSbound Hpg or on the nascent peptide.

\section{Genes for self-resistance, regulation and export}

The mechanism(s) employed by the enduracidin and ramoplanin producers to protect intracellular Lipid I and Lipid II from being complexed by these peptide antibiotics is still unknown. Self-resistance mechanisms for cell-wallactive glycopeptide antibiotics like vancomycin typically involve alteration of the terminal residue of the pentapeptide moiety of Lipid II (Marshall et al., 1998; Li et al., 2004). Our partial scan of the S. fungicidicus genome identified vancomycin-type resistance genes (data not shown), but this mechanism is unlikely to be related to enduracidin 
self-resistance because the peptides recognize different regions of Lipid II and enduracidin is active against vancomycin-resistant bacteria. In other lipopeptide biosynthetic gene clusters, such as those for daptomycin, CDA and ramoplanin, the identity of the genes conferring antibiotic immunity also remains unknown. Export of the peptide from the cell is likely to involve Orf31, Orf32 and Orf33, predicted to function as components of $\mathrm{ABC}$ transporters similar to those in other antibiotic biosynthetic gene clusters. Regulation of antibiotic production, and possibly self-resistance determinant expression, is believed to involve orf22, orf24, orf41, orf42 and orf43. Orf41 is similar to the LuxR family of DNA-binding proteins that are activated by bacterial autoinducer molecules (Demain, 1998). orf42 and orf43 encode elements of two-component sensor kinase systems such as those activating expression of vancomycin resistance genes and orf 22 and orf 24 also exhibit similarity to known regulatory genes in other secondary metabolite clusters. All of these putative regulatory genes have orthologues in the ramoplanin cluster (Table 1).

\section{Boundaries and remaining genes identified in the end cluster}

The probable boundaries of the end cluster were assigned based on the deduced functions of the end and flanking gene products and by comparison with the ramoplanin gene cluster. With the possible exception of orf 10 being involved in lipid tail formation, there are no ORFs in the sequenced region upstream of orf 22 with predicted functions necessary for enduracidin formation. Likewise, the region located downstream of orf 46 has no ramoplanin counterparts or genes with a possible function in enduracidin biosynthesis. Therefore, we propose the boundaries of the enduracidin gene cluster are defined by orf 22 and orf 46 . Whether any of the genes in the flanking regions that encode products of unknown function are involved in antibiotic regulation or resistance remains to be determined.

\section{Conclusion}

Enduracidin and the closely related ramoplanin are members of a novel class of peptide antibiotics with promising activity against serious infections caused by Gram-positive pathogens. The unique mechanism of action shared by these peptides results in a lack of cross-resistance with other known classes of bacterial cell-wall inhibitors and makes the development of improved analogues an attractive pursuit. The sequenced end cluster offers opportunities to study the formation of the rare amino acid enduracididine, will allow studies on the unknown mechanism of enduracidin self-resistance and provides the means to explore the scope and limitations of using dual action C/E domains in actinomycete NRPS systems. Importantly, knowledge of the sequence and organization of the end cluster and the demonstrated ability to genetically manipulate $S$. fungicidicus should accelerate the development of novel analogues through a combined genetic and chemical approach.

\section{ACKNOWLEDGEMENTS}

We are grateful to Dr Ling Zhang for excellent technical support and to Professor Keith F. Chater for providing plasmid pSET152. This work was supported in part by National Institutes of Health grant GM69320 (M.Z.) and by funds from the Oregon State University College of Pharmacy Research and Scholarship Fund, the OSU General Research Fund and the Medical Research Foundation of Oregon (X. Y.).

\section{REFERENCES}

Altschul, S. F., Gish, W., Miller, W., Myers, E. W. \& Lipman, D. J. (1990). Basic local alignment search tool. J Mol Biol 215, 403-410.

Balibar, C. J., Vaillancourt, F. H. \& Walsh, C. T. (2005). Generation of D-amino acid residues in assembly of arthrofactin by dual condensation/epimerization domains. Chem Biol 12, 1189-1200.

Barrett, J. (2005). Recent developments in glycopeptide antibacterials. Curr Opin Invest Drugs 6, 781-790.

Bierman, M. R., Logan, R., O'Brien, K., Seno, E. T., Rao, R. N. \& Shoner, B. E. (1992). Plasmid cloning vectors for the conjugal transfer of DNA from Escherichia coli to Streptomyces spp. Gene 116, 43-49.

Challis, G. L., Ravel, J. \& Townsend, C. A. (2000). Predictive, structure-based model of amino acid recognition by nonribosomal peptide synthetase adenylation domains. Chem Biol 7, 211-224.

Chiu, H. T., Hubbard, B. K., Shah, A. N., Eide, J., Fredenburg, R. A., Walsh, C. T. \& Khosla, C. (2001). Molecular cloning and sequence analysis of the complestatin biosynthetic gene cluster. Proc Natl Acad Sci U S A 98, 8548-8553.

Choroba, O. W., Williams, D. H. \& Spencer, J. B. (2000). Biosynthesis of the vancomycin group of antibiotics: involvement of an unusual dioxygenase in the pathway to (S)-4-hydroxyphenylglycine. J Am Chem Soc 122, 5389-5390.

Cudic, P., Kranz, J. K., Behenna, D. C., Kruger, R. G., Tadesse, H., Wand, A. J., Veklich, Y. I., Weisel, J. W. \& McCafferty, D. G. (2002). Complexation of peptidoglycan intermediates by the lipoglycodepsipeptide antibiotic ramoplanin: minimal structural requirements for intermolecular complexation and fibril formation. Proc Natl Acad Sci U S A 99, 7384-7389.

Demain, A. L. (1998). Induction of microbial secondary metabolism. Int Microbiol 1, 259-264.

Dorrestein, P. C., Yeh, E., Garneau-Tsodikova, S., Kelleher, N. L. \& Walsh, C. T. (2005). Dichlorination of a pyrrolyl-S-carrier protein by $\mathrm{FADH}_{2}$-dependent halogenase PltA during pyoluteorin biosynthesis. Proc Natl Acad Sci U S A 102, 13843-13848.

Duitman, E. H., Hamoen, L. W., Rembold, M. \& 10 other authors (1999). The mycosubtilin synthetase of Bacillus subtilis ATCC 6633: a multifunctional hybrid between a peptide synthetase, an amino transferase, and a fatty acid synthase. Proc Natl Acad Sci U S A 96, 13294-13299.

Fang, X., Tiyanont, K., Zhang, Y., Vanner, J., Boger, D. \& Walker, S. (2006). The mechanism of action of ramoplanin and enduracidin. Mol BioSyst 2, 69-76.

Goto, S., Kuwahara, S., Okubo, N. \& Zenyoji, H. (1968). In vitro and in vivo evaluation of enduracidin, a new peptide antibiotic substance. $J$ Antibiot 21, 119-125.

Guenzi, E., Galli, G., Grgurina, I., Gross, D. C. \& Grandi, G. (1998). Characterization of the syringomycin synthetase gene cluster. A link between prokaryotic and eukaryotic peptide synthetases. J Biol Chem 273, 32857-32863.

Haltli, B., Tan, Y., Magarvey, N. A., Wagenaar, M., Yin, X., Greenstein, M., Hucul, J. A. \& Zabriskie, T. M. (2005). 
Investigating beta-hydroxyenduracididine formation in the biosynthesis of the mannopeptimycins. Chem Biol 12, 1163-1168.

Hatano, K., Nogami, I., Higashide, E. \& Kishi, T. (1984). Biosynthesis of enduracidin: origin of enduracididine and other amino acids. Agric Biol Chem 48, 1503-1508.

He, H., Williamson, R. T., Shen, B., Graziani, E. I., Yang, H. Y., Sakya, S. M., Petersen, P. J. \& Carter, G. T. (2002). Mannopeptimycins, novel antibacterial glycopeptides from Streptomyces hygroscopicus, LL-AC98. J Am Chem Soc 124, 9729-9736.

Heinzelmann, E., Berger, S., Muller, C., Hartner, T., Poralla, K., Wohlleben, W. \& Schwartz, D. (2005). An acyl-CoA dehydrogenase is involved in the formation of the $\Delta$ cis 3 double bond in the acyl residue of the lipopeptide antibiotic friulimicin in Actinoplanes friuliensis. Microbiology 151, 1963-1974.

Higashide, E., Hatano, K., Shibata, M. \& Nakazawa, K. (1968). Enduracidin, a new antibiotic. I. Streptomyces fungicidicus No. B5477, an enduracidin producing organism. J Antibiot 21, 126-137.

Hojati, Z., Milne, C., Harvey, B. \& 9 other authors (2002). Structure, biosynthetic origin, and engineered biosynthesis of calcium-dependent antibiotics from Streptomyces coelicolor. Chem Biol 9, 1175-1187.

Hori, M., Iwasaki, H., Horii, S., Yoshida, I. \& Hongo, T. (1973). Enduracidin, a new antibiotic. VII. Primary structure of the peptide moiety. Chem Pharm Bull 21, 1175-1183.

Hubbard, B. K., Thomas, M. G. \& Walsh, C. T. (2000). Biosynthesis of L-p-hydroxyphenylglycine, a non-proteinogenic amino acid constituent of peptide antibiotics. Chem Biol 7, 931-942.

Ishikawa, J., Yamashita, A., Mikami, Y., Hoshino, Y., Kurita, H., Hotta, K., Shiba, T. \& Hattori, M. (2004). The complete genomic sequence of Nocardia farcinica IFM 10152. Proc Natl Acad Sci U S A 101, 14925-14930.

Iwasaki, H., Horii, S., Asai, M., Mizuno, K., Ueyanagi, J. \& Miyake, A. (1973). Enduracidin, a new antibiotic. VIII. Structures of enduracidin A and B. Chem Pharm Bull 21, 1184-1191.

Ju, J., Ozanick, S. G., Shen, B. \& Thomas, M. G. (2004). Conversion of $(2 S)$-arginine to $(2 S, 3 R)$-capreomycidine by VioC and VioD from the viomycin biosynthetic pathway of Streptomyces sp. strain ATCC 11861. Chembiochem 5, 1281-1285.

Kawakami, M., Nagai, Y., Fujii, T. \& Mitsuhashi, S. (1971). Antimicrobial activities of enduracidin (enramycin) in vitro and in vivo. $J$ Antibiot 24, 583-586.

Keller, S., Wage, T., Hohaus, K., Holzer, M., Eichhorn, E. \& van Pee, K. H. (2000). Purification and partial characterization of tryptophan 7-halogenase (PrnA) from Pseudomonas fluorescens. Angew Chem Int Ed Engl 39, 2300-2302.

Kieser, T., Bibb, M. J., Buttner, M. J., Charter, K. F. \& Hopwood, D. A. (2000). Practical Streptomyces Genetics. Norwich: John Innes Centre. Komatsuzawa, H., Suzuki, J., Sugai, M., Miyake, Y. \& Suginaka, H. (1994). Effect of combination of oxacillin and non-beta-lactam antibiotics on methicillin-resistant Staphylococcus aureus. J Antimicrob Chemother 33, 1155-1163.

Li, T. L., Huang, F., Haydock, S. F., Mironenko, T., Leadlay, P. F. \& Spencer, J. B. (2004). Biosynthetic gene cluster of the glycopeptide antibiotic teicoplanin: characterization of two glycosyltransferases and the key acyltransferase. Chem Biol 11, 107-119.

Linne, U., Doekel, S. \& Marahiel, M. A. (2001). Portability of epimerization domain and role of peptidyl carrier protein on epimerization activity in nonribosomal peptide synthetases. Biochemistry 40, 15824-15834.

Mangili, A., Bica, I., Snydman, D. R. \& Hamer, D. H. (2005). Daptomycin-resistant, methicillin-resistant Staphylococcus aureus bacteremia. Clin Infect Dis 40, 1058-1060.
Marahiel, M. A., Stachelhaus, T. \& Mootz, H. D. (1997). Modular peptide synthetases involved in nonribosomal peptide synthesis. Chem Rev 97, 2651-2674.

Marshall, C. G., Lessard, I. A., Park, I. \& Wright, G. D. (1998), Glycopeptide antibiotic resistance genes in glycopeptide-producing organisms. Antimicrob Agents Chemother 42, 2215-2220.

McCafferty, D. G., Cudic, P., Frankel, B. A., Barkallah, S., Kruger, R. G. \& Li, W. (2002). Chemistry and biology of the ramoplanin family of peptide antibiotics. Biopolymers 66, 261-284.

Meka, V. G., Pillai, S. K., Sakoulas, G. \& 7 other authors (2004). Linezolid resistance in sequential Staphylococcus aureus isolates associated with a T2500A mutation in the 23S rRNA gene and loss of a single copy of rRNA. J Infect Dis 190, 311-317.

Miao, V., Coeffet-LeGal, M. F., Brian, P. \& 10 other authors (2005). Daptomycin biosynthesis in Streptomyces roseosporus: cloning and analysis of the gene cluster and revision of peptide stereochemistry. Microbiology 151, 1507-1523.

Miao, V., Brost, R., Chapple, J., She, K., Gal, M. F. \& Baltz, R. H. (2006). The lipopeptide antibiotic A54145 biosynthetic gene cluster from Streptomyces fradiae. J Ind Microbiol Biotechnol 33, 129-140.

Paulsen, I. T., Press, C. M., Ravel, J. \& 26 other authors (2005). Complete genome sequence of the plant commensal Pseudomonas fluorescens Pf-5. Nat Biotechnol 23, 873-878.

Peromet, M., Schoutens, E. \& Yourassowsky, E. (1973). Clinical and microbiological study of enduracidin in infections due to methicillin-resistant strains of Staphylococcus aureus. Chemotherapy 19, 53-61.

Pootoolal, J., Thomas, M. G., Marshall, C. G., Neu, J. M., Hubbard, B. K., Walsh, C. T. \& Wright, G. D. (2002). Assembling the glycopeptide antibiotic scaffold: the biosynthesis of A47934 from Streptomyces toyocaensis NRRL15009. Proc Natl Acad Sci U S A 99, 8962-8967.

Puk, O., Huber, P., Bischoff, D., Recktenwald, J., Jung, G., Sussmuth, R. D., van Pee, K. H., Wohlleben, W. \& Pelzer, S. (2002). Glycopeptide biosynthesis in Amycolatopsis mediterranei DSM5908: function of a halogenase and a haloperoxidase/perhydrolase. Chem Biol 9, 225-235.

Rausch, C., Weber, T., Kohlbacher, O., Wohlleben, W. \& Huson, D. H. (2005). Specificity prediction of adenylation domains in nonribosomal peptide synthetases (NRPS) using transductive support vector machines (TSVMs). Nucleic Acids Res 33, 5799-5808.

Recktenwald, J., Shawky, R., Puk, O., Pfennig, F., Keller, U., Wohlleben, W. \& Pelzer, S. (2002). Nonribosomal biosynthesis of vancomycin-type antibiotics: a heptapeptide backbone and eight peptide synthetase modules. Microbiology 148, 1105-1118.

Roongsawang, N., Hase, K., Haruki, M., Imanaka, T., Morikawa, M. \& Kanaya, S. (2003). Cloning and characterization of the gene cluster encoding arthrofactin synthetase from Pseudomonas sp. MIS38. Chem Biol 10, 869-880.

Sambrook, J. \& Russell, D. V. (2001). Molecular Cloning: a Laboratory Manual, 3rd edn. Cold Spring Harbor, NY: Cold Spring Harbor Laboratory.

Scholz-Schroeder, B. K., Soule, J. D. \& Gross, D. C. (2003). The sypA, sypS, and sypC synthetase genes encode twenty-two modules involved in the nonribosomal peptide synthesis of syringopeptin by Pseudomonas syringae pv. syringae B301D. Mol Plant Microbe Interact 16, 271-280.

Sosio, M., Stinchi, S., Beltrametti, F., Lazzarini, A. \& Donadio, S. (2003). The gene cluster for the biosynthesis of the glycopeptide antibiotic A40926 by Nonomuraea species. Chem Biol 10, 541-549. 
Stachelhaus, T., Mootz, H. D. \& Marahiel, M. A. (1999). The specificity-conferring code of adenylation domains in nonribosomal peptide synthetases. Chem Biol 6, 493-505.

Tenover, F. C. \& McDonald, L. C. (2005). Vancomycin-resistant staphylococci and enterococci: epidemiology and control. Curr Opin Infect Dis 18, 300-305.

Trauger, J. W. \& Walsh, C. T. (2000). Heterologous expression in Escherichia coli of the first module of the nonribosomal peptide synthetase for chloroeremomycin, a vancomycin-type glycopeptide antibiotic. Proc Natl Acad Sci U S A 97, 3112-3117.

Tsiodras, S., Gold, H. S., Sakoulas, G., Eliopoulos, G. M., Wennersten, C., Venkataraman, L., Moellering, R. C. \& Ferraro, M. J. (2001). Linezolid resistance in a clinical isolate of Staphylococcus aureus. Lancet 358, 207-208.

Tsuchiya, K., Kondo, M., Oishi, T. \& Yamazaki, I. (1968). Enduracidin, a new antibiotic. 3. In vitro and in vivo antimicrobial activity. J Antibiot 21, 147-153.

Vaillancourt, F. H., Yeh, E., Vosburg, D. A., O'Connor, S. E. \& Walsh, C. T. (2005). Cryptic chlorination by a non-haem iron enzyme during cyclopropyl amino acid biosynthesis. Nature 436, 1191-1194.

van Wageningen, A. M., Kirkpatrick, P. N., Williams, D. H., Harris, B. R., Kershaw, J. K., Lennard, N. J., Jones, M., Jones, S. J. \& Solenberg, P. J. (1998). Sequencing and analysis of genes involved in the biosynthesis of a vancomycin group antibiotic. Chem Biol 5, 155-162.
Walker, S., Chen, L., Hu, Y., Rew, Y., Shin, D. \& Boger, D. L. (2005). Chemistry and biology of ramoplanin: a lipoglycodepsipeptide with potent antibiotic activity. Chem Rev 105, 449-476.

Wright, F. \& Bibb, M. J. (1992). Codon usage in the $G+C$-rich Streptomyces genome. Gene 113, 55-65.

Yeh, E., Garneau, S. \& Walsh, C. T. (2005). Robust in vitro activity of RebF and RebH, a two-component reductase/halogenase, generating 7-chlorotryptophan during rebeccamycin biosynthesis. Proc Natl Acad Sci U S A 102, 3960-3965.

Yin, X. \& Zabriskie, T. M. (2004). VioC is a non-heme iron, $\alpha$ ketoglutarate dependent oxygenase that catalyzes the formation of 3S-hydroxy-L-arginine during viomycin biosynthesis. Chembiochem 5, 1274-1277.

Yin, X., O'Hare, T., Gould, S. J. \& Zabriskie, T. M. (2003). Identification and cloning of genes encoding viomycin biosynthesis from Streptomyces vinaceus and evidence for involvement of a rare oxygenase. Gene 312, 215-224.

Yin, X., McPhail, K. L., Kim, K. J. \& Zabriskie, T. M. (2004). Formation of the nonproteinogenic amino acid 2S,3R-capreomycidine by VioD from the viomycin biosynthesis pathway. Chembiochem 5, 1278-1281.

Yourassowsky, E. \& Monsieur, R. (1972). In vitro and in vivo activity of enduracidin on Staphylococcus aureus. Chemotherapy 17, 182-187.

Zinner, S. H. (2005). The search for new antimicrobials: why we need new options. Expert Rev Anti Infect Ther 3, 907-913. 